\title{
TNF Gene
}

National Cancer Institute

\section{Source}

National Cancer Institute. TNF Gene. NCI Thesaurus. Code C18368.

This gene is involved in apoptosis, cell growth and cell proliferation. It also plays a role in immune and inflammatory responses. 